\title{
First Hydrogelation of Discrete Metal Complexes. Structures and Fluxional Behavior of Cyclopalladium(II) Complexes
}

\author{
Young Mee Na, Tae Hwan Noh, Byung Jo Ha, ${ }^{\dagger}$ Jongki Hong,,${ }^{\ddagger}$ and OK-Sang Jung \\ Department of Chemistry Ptsan National Lniversity, Pusan 609-735, Korea. ${ }^{*}$ E-mail oksjungapusanackr \\ -Department of Dermatic Health Management, Eulli Universinv Seongnam +61-713. Korea \\ "College of Pharmacy Kytng Hee University, Seoul 130-701, Korea \\ Received October 31, 2008, Accepted December 15, 2008
}

\begin{abstract}
The reaction of $(\mathrm{en}) \mathrm{Pd}\left(\mathrm{NO}_{3}\right)_{2}$ (en = ethylenediamine) with 1,4-bis(dimethy 1-4-pyridylsilyl)benzene ( $\mathrm{L}$ ) affords cyclodimer, $[(\mathrm{en}) \operatorname{Pd}(\mathrm{L})]_{2}\left(\mathrm{NO}_{3}\right)_{4}$, whereas the reaction of $($ tmeda $) \mathrm{Pd}\left(\mathrm{NO}_{3}\right)_{2}$ (tmeda $=\mathrm{N}, \mathrm{N}, \mathrm{N}_{1}, \mathrm{~N}^{-}$-tetramethylethylenediamine) with $\mathrm{L}$ gives cyclotrimer; $[(\text { tmeda }) \mathrm{Pd}(\mathrm{L})]_{3}\left(\mathrm{NO}_{3}\right)_{\mathrm{i}}$. Both complexes exist as catenane in water. The catenated cyclodimer is rigid whereas the catenated cyclotrimer is dynamic in water. The catenated cyclotrimers afford hydrogel containing $98.5 \%$ water below $2{ }^{\circ} \mathrm{C}$. The hydrogel changes to its sol around $38^{\circ} \mathrm{C}$, and to its clear solution at $78^{\circ} \mathrm{C}$. Such a notable difference between $\left[\left(e_{1}\right) \mathrm{Pd}(\mathrm{L})\right]_{2}\left(\mathrm{NO}_{3}\right)_{4}$ and $\left.\left[\left(\mathrm{tm}^{2} \mathrm{eda}\right) \mathrm{Pd}(\mathrm{L})\right]_{3}(\mathrm{NO})_{3}\right)_{i}$ might be explained by their different dynamic behavior via ring size effects.
\end{abstract}

Key Words: Catenane. Hydrogelation. Metallacycles. Palladium. Si ligands

\section{Introduction}

Research on the prediction and control of bulk properties on the basis of molecular stnicture and motion is a current important issue ${ }^{1-3}$ One aspect of particular interest is the formation of stimuli-responsive hydrogels that have potential applications such as foods. cosmetics, textile fibers, drug delivery agents. superabsorbents. and tissue engineering scaffolds. In particular. supramolecular self-assembly through weak intermolecular interactions has been employed as a general method for the formation of task-specific hydrogels. ${ }^{8.9}$ These weak intermolecular interactions, via intermediary water molecules are a significant factor in hyddrogelation of polymeric compounds. Whereas numerous organic/polymeric hydrogels have been developed. ${ }^{1(1+13}$ reversible hydrogelation of discrete metal complexes is to our best knowledge. unprecedented. Discrete organic molecules such as steroids, carbolydrates. anthryl derivatives. and urea have been known to form useful lydrogels. ${ }^{14-1 \text { ? }}$

On the other hand, the ability to control metallacyclic rings by means of chemical triggers is of importance in the construction of molecular machines. recognition. selective transformation. catalysts. storage and biomimics materials. ${ }^{18-i)}$ Simple, readily applicable controllable methods of rings are ring-expansion and the "magic ring" phenomenon by means of labile $\mathrm{Pd}-\mathrm{N}$ dual character ${ }^{21-23}$ Hydrogelation via the fluxional motion of such discrete cyclopalladium(II) complexes remains a tough challenge.

In this context. we report the first hydrogelation and sructural properties of a fluxional cyclopalladium(II) sỵstem along with coligand effects. Our first goal was to achieve the coligand effects of the $\mathrm{Pd}-\mathrm{N}$ bonding properties, but this was also an unprecedented reversible hydrogelation of discrete palladium(II) complex in water. These materials undergo a well characterized sol $\leftrightarrow$ gel transition (sol $\rightarrow$ gel below $2{ }^{\circ} \mathrm{C}$ : gel $\rightarrow$ sol above $38^{\circ} \mathrm{C}$ ).

\section{Experimental Section}

Materials and Measurements. Potassium tetrachloropalladate $\left.\left(\mathrm{K}_{2} \mathrm{PdCl}_{4}\right), X_{1}, N_{,}\right)^{\prime}, N^{\prime}$ '-tetramethylethylenediamine (tmeda). ethylenedianine (en), 1,4-bis(cllorodimethylsiyl)benzene, and $\mathrm{AgNO}_{3}$ were purchased from Aldrich. and used without further purification. (en) $\mathrm{PdCl}_{2}$ and (tmeda) $\mathrm{PdCl}_{2}$ were prepared by the literature procedure. ${ }^{24} 1.4-\mathrm{Bis}$ (dimethyl-4-pyridylsilyl)benzene $(\mathrm{L})$ was prepared by a method outlined in two of our previous literatures. ${ }^{25.26}{ }^{9} \mathrm{H}$ NMR spectra were recorded on a Varian Mercury Plus 300 operating at 300.00 $\mathrm{MHz}$, and the chemical shifts were relative to the internal $\mathrm{Me}_{4} \mathrm{Si}$. Infrared spectra were obtained on a Perkin Elmer I6F PC FTIR spectrophotometer with samples prepared as $\mathrm{KBr}$ pellet. Elemental nicroanaly ses $(\mathrm{C} . \mathrm{H}, \mathrm{N}$ ) were performed on solid samples by the Advanced Analytical Division at Pusan Center, KBSI using a Perkin Elmer 2400 CHNS analyzer. Mass spectrometric analysis was performed in chloroform by KMS-700 Mstation Mass Spectrometer (Jeol, Japan) using a MS-MP9020D data system. High resolution transmission electron microscope images were obtained by a Phillips model CM $200 \mathrm{HR}$-TEM, and scanning electron nicroscope images were obtained on a JEM $201 \mathrm{l}$.

Preparation of $[(\text { tmedla }) \mathrm{Pd}(\mathbf{L})]_{3}\left(\mathrm{NO}_{3}\right)_{6}$. (tmeda) $\mathrm{PdCl}_{2}(45$ mg. $0.15 \mathrm{mmol}$ ) was suspended in water $(15 \mathrm{~mL})$ and stirred for $2 \mathrm{~h}$ at $50{ }^{\circ} \mathrm{C}$ with $\mathrm{AgNO}_{3}(5 \mathrm{lmg} .0 .3 \mathrm{mmol}$ ). After the mixture was cooled and $\mathrm{AgCl}$ removed by filtration a methanol $(10 \mathrm{~mL})$ solution of $\mathrm{L}(53 \mathrm{mg} .0 .15 \mathrm{mmol})$ was added to the filtrate, and the mixture stirred for $3 \mathrm{~h}$ at room temperature. The solution was then filtered and evaporated to dryness to yield the yellow solid under vacuum. ${ }^{1} \mathrm{H}$ NMR ( 300 $\mathrm{MHz}, \mathrm{D}_{2} \mathrm{O}, \delta$ ) of $\mathbf{T}$ (cyclotrimer): $0.38\left(\mathrm{~s} . \mathrm{CH}_{3}\right), 2.51\left(\mathrm{~s}, \mathrm{CH}_{3}\right)$. 2.92 (s. $-\mathrm{NCH}_{2} \mathrm{CH}_{2} \mathrm{~N}-$ ). 7.06 (s. $\left.\mathrm{C}_{6} \mathrm{H}_{4}\right) .7 .38$ (d. $J=5.7 \mathrm{~Hz}$. $\left.\mathrm{PyH}_{\beta}\right) .8 .60\left(\mathrm{~d} . J=5.7 \mathrm{~Hz}, \mathrm{PyH}_{(\mathrm{r})}\right.$. CT (catenated cyclotrimer): 0.25 (s. $\left.\mathrm{CH}_{3}\right), 2.51$ (s. $\mathrm{CH}_{3}$ ), 2.92 (s. $-\mathrm{NCH}_{2} \mathrm{CH}_{2} \mathrm{~N}$ ), 6.20 (s. $\left.\mathrm{C}_{6} \mathrm{H}_{4}\right) .7 .45\left(\mathrm{~d}, J=5.7 \mathrm{~Hz}, \mathrm{PyH}_{\beta}\right) .8 .77$ (d. $J=5.7 \mathrm{~Hz}, \mathrm{PyH}_{(\mathrm{r})}$ ). 
IR $\left(\mathrm{KBr} . \mathrm{cm}^{-1}\right): r^{\prime}=3435(\mathrm{~m}) .1604(\mathrm{w}) .1383(\mathrm{~s}) .1130(\mathrm{w})$. $809(\mathrm{~m})$. 506(w). Anal. Calcd for $\mathrm{C}_{78} \mathrm{H}_{120} \mathrm{~N}_{18} \mathrm{O}_{18} \mathrm{Pd}_{3} \mathrm{Si}_{6} \mathrm{C}$. 44.92: H. $5.80:$ N. 12.09. Found: C. 44.96: H. 5.87: N. 12.03 .

Pieparation of $[(\mathbf{e n}) \mathbf{P d}(\mathbf{L})]_{2}\left(\mathbf{N O}_{3}\right)_{4}$ ( (en) $\mathrm{PdCl}_{2}$ (36 mg. 0.15 mmol) was suspended in water ( $15 \mathrm{~mL}$ ) and stirred for $2 \mathrm{~h}$ at $50^{\circ} \mathrm{C}$ with $\mathrm{AgNO}_{3}(51 \mathrm{mg} .0 .3 \mathrm{mmol})$. After the mixture was cooled and $\mathrm{AgCl}$ removed by filtration. a methanol ( $10 \mathrm{~mL}$ ) solution of L (53 mg. $0.15 \mathrm{mmol}$ ) was added to the filtrate. and the mixture stirred for $3 \mathrm{~h}$ at room temperature. The solution was then filtered and eraporated to dry ness to sield the yellow solid under vacuum. ${ }^{1} \mathrm{H}$ NMR $\left(300 \mathrm{MH} \% \mathrm{D}_{2} \mathrm{O} . \delta\right.$ ) of D (c) clodimer): $0.38\left(\mathrm{~s}, \mathrm{CH}_{3}\right), 2.75\left(\mathrm{~s},-\mathrm{NCH}_{2} \mathrm{CH}_{2} \mathrm{~N}-\right), 7.18$ (s, $\left.\mathrm{C}_{6} \mathrm{H}_{4}\right) .7 .34\left(\mathrm{~d} . J=6.6 \mathrm{H} \% \mathrm{P}_{y} \mathrm{H}_{\beta}\right) .8 .38\left(\mathrm{~d} . J=6.6 \mathrm{H} / . \mathrm{P}_{5} \mathrm{H}_{0}\right)$. CD (calenated cyclodimer); $0.38\left(\mathrm{~s} .24 \mathrm{H} . \mathrm{CH}_{3}\right) .2 .75(\mathrm{~s} .8 \mathrm{H}$. $\left.-\mathrm{VCH}_{2} \mathrm{CH}_{2} \mathrm{~N}-\right) .5 .78$ (s, $\mathrm{C}_{6} \mathrm{H}_{4}-$ inside). $6.88(\mathrm{~d}, J=6.6 \mathrm{H} \%$ $\mathrm{PyH}_{\beta}$ - inside). 7.02 (s. $\mathrm{C}_{6} \mathrm{H}_{4}$-outside). 7.54 (d. $J=6.6 \mathrm{H} /$.

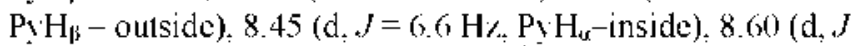
$=6.6 \mathrm{H} \%$ Py $\mathrm{H}_{\alpha}$-outside). IR $\left(\mathrm{KBr} . \mathrm{cm}^{-1}\right): \gamma=3050(w) .2054(\mathrm{w})$. $1604(\mathrm{w}), 1384(\mathrm{~s}), 1252(\mathrm{~m}), 1133(\mathrm{~m}), 1059(\mathrm{w}), 803(\mathrm{~m})$, $775(\mathrm{~m})$. 670(w). 49(m). Anal. Calcd for $\mathrm{C}_{44} \mathrm{H}_{64} \mathrm{~N}_{12}$ $\mathrm{O}_{12} \mathrm{Pd}_{2} \mathrm{Si}_{4}: \mathrm{C} .41 .34:$ H. 5.05: N. 13.15. Found: C. 41.37: H. 5.15: N, 13.11.

Hydrogelation of $\mid(\text { tmeda) } \mathbf{P d}(\mathrm{L})]_{3}\left(\mathrm{NO}_{3}\right)_{6}$. The reaction of an aqueous solution $(15 \mathrm{~mL})$ of (1meda) Pd( $\left.\mathrm{NO}_{3}\right)_{2}(45 \mathrm{mg}$, (). $15 \mathrm{mmol}$ ) with a methanol $(10 \mathrm{~mL})$ solution of $\mathrm{L}(53 \mathrm{mg}$.

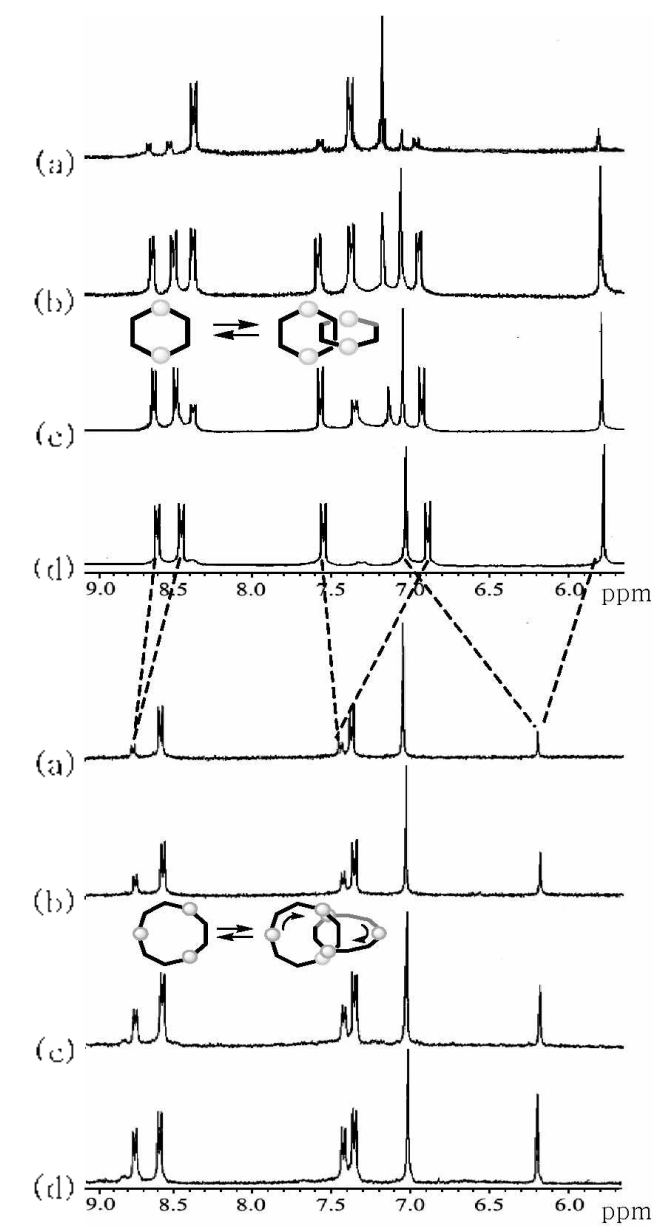

Fïgure 1. Concentration-dependent ${ }^{1} \mathrm{H}$ NMR of $|(\mathrm{en}) \mathrm{Pd}(\mathrm{L})|_{2}\left(\mathrm{NO}_{3}\right)_{1}$ (1op: $2 \mathrm{mM}$ (a). $10 \mathrm{mM}$ (b). $25 \mathrm{mM}$ (c). $50 \mathrm{mM}$ (d)) and l(tmeda)$\mathrm{Pd}(\mathrm{L}) \mid:\left(\mathrm{NO}_{3}\right)_{i}$ (botion: $2 \mathrm{mM}$ (a). $5 \mathrm{mM}$ (b). $10 \mathrm{mM}$ (c). $15 \mathrm{mM}$ (d)).
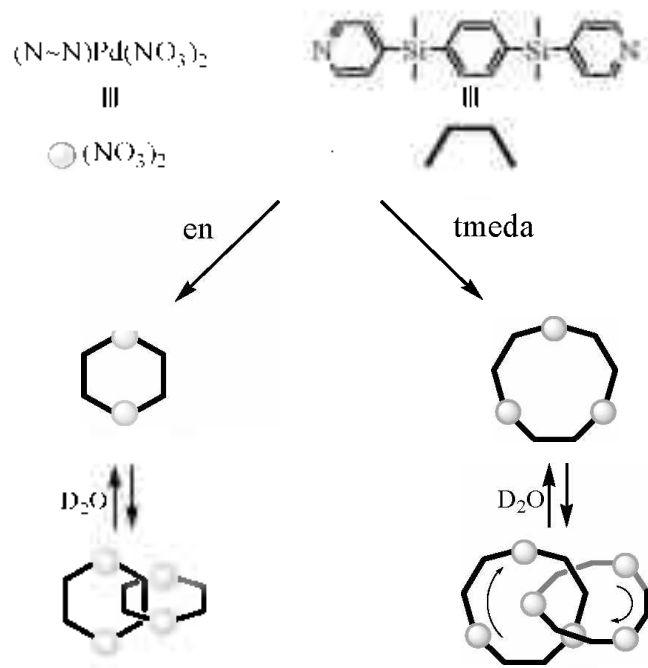

$\mathrm{D}_{2} \mathrm{O} \uparrow$
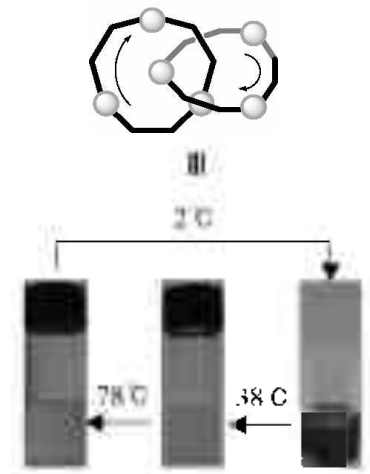

Scheme 1

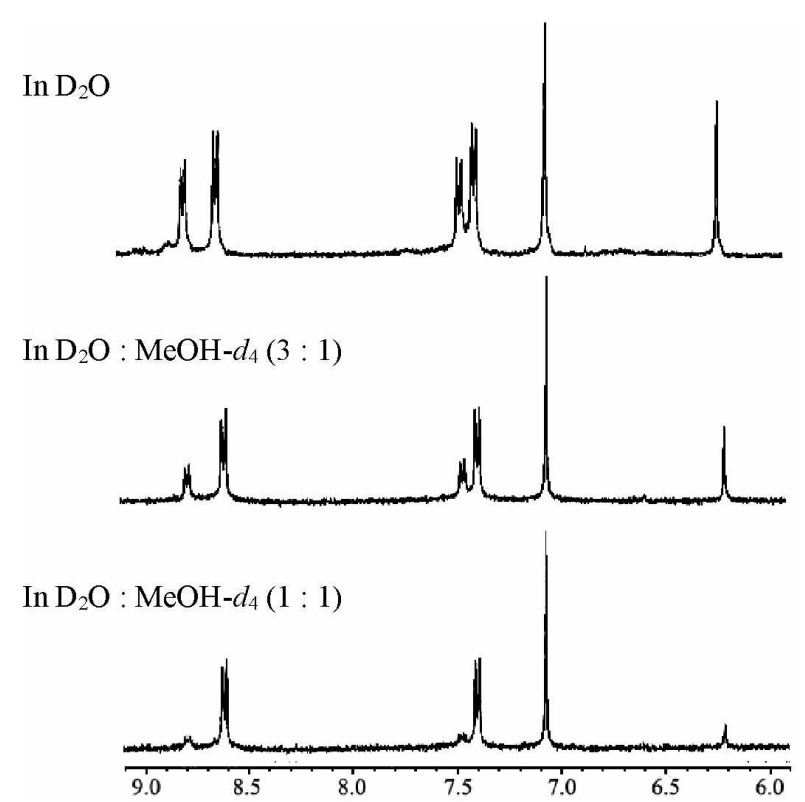

Figure 2. 'H NMR spectra ol $\left(\right.$ (tmeda) $\left.\mathrm{Pd}(\mathrm{L})\right|_{3}\left(\mathrm{NO}_{3}\right)_{6}$ in a mixlure of $\mathrm{D} \_\mathrm{O}$ and $\mathrm{MeOH}-\mathrm{ll}_{4}$ ( $\left.15 \mathrm{mM}\right)$.

$0.15 \mathrm{mmol}$ ) was carried out for $3 \mathrm{~h}$ at room temperalure. The reaction solution was filtered and reduced to an aqueous solution of $5 \mathrm{~mL}$. The safe-keeping of the aqueous solution below $2^{\circ} \mathrm{C}$ affords hydrogel containing $98.5 \%$ water.

\section{Results and Discussion}

Synthesis. The reaction of (en)Pd( $\left.\mathrm{NO}_{3}\right)_{2}$ (en - ethylenediamine) with 1.4-bis(dimethyl-4-pyridy silyl)benzene (L) in 
a mixture of water and methanol at room temperature vields the crclodimer (D). $|(\mathrm{cr}) \mathrm{Pd}(\mathrm{L})|_{2}\left(\mathrm{NO}_{3}\right)_{4}$. whereas the reaction of (tmeda) $\mathrm{Pd}\left(\mathrm{NO}_{3}\right)_{2}$ (meda $=N, N^{*}, N^{*}$-tetramelhy]cthylenedianine) with $[$, produces the exclotrinter $(\mathbf{T}) \mid($ tnieda) $\left.\mathrm{Pd}(\mathrm{L})\right|_{3}\left(\mathrm{NO}_{3}\right)_{6}$ (Scheme 1). The water-solubility of $\mid(\mathrm{cn}) \mathrm{P}^{3} \mathrm{~d}-$ (L) $:\left(\mathrm{NO}_{3}\right)_{4}$ is better than that of $\mid\left.($ tmeda $) \mathrm{Pd}(\mathrm{L})\right|_{3}\left(\mathrm{NO}_{3}\right)_{3}$, and both complexes are stable in solid state. Thus. the metallacyclization is significantly affectod by coligands. The formation of products scems to be induced from the steric difference between tmeda and en rather than from electronic difference. The bulky tmeda prefers $\mathbf{T}$ to $\mathbf{D}$ in order to decrease the ring constraint

Fonmation of Catenane. The ${ }^{\mathrm{j}} \mathrm{H}$ NMR spectra in water at room temperature indicate the equilibrium between the metallacycles and its corresponding eatenanes. Figure I shows the concentration-dependent ${ }^{1} \mathrm{H}$ NMR. indicating that the high concentration favors catcnation. The signals of the pvridyl and phenyl groups exhibited two sets of ${ }^{1} \mathrm{H}$ resonances. confirming the cocxistence of two species in the solution. [(cn) $\left.\mathrm{Pd}(\mathrm{L})\right|_{2}\left(\mathrm{NO}_{3}\right)_{4}$ in low concentrations predominantly exists as $D$, and the increase of the concentration resulted in the growth of the catenated cyelodimer (CD) pcaks, and finally D was completely converted to CD. The two signals $(8.60,8.45 ; 7.54,6.88 ; 7.02,5.78 \mathrm{ppm})$ of cach peak reflected the catenane. The signal at $7.18 \mathrm{ppm}$ of $\mathbf{D}$ scparated into two signals at $7.02 \mathrm{ppm}$ (outside $-\mathrm{C}_{6} \mathrm{H}_{4-}$ ) and $5.78 \mathrm{ppm}$ (inside $\left.-\mathrm{C}_{6} \mathrm{H}_{4}-\right)$. [(1meda) $\left.\mathrm{Pd}(\mathrm{L})\right]_{3}\left(\mathrm{NO}_{3}\right)_{\mathrm{i}}$ similarly coexists as $\mathbf{T}$ and $\mathbf{C T}$ in the aqueous solution. The NMR spectra indicate that linear and higher oligomers do not cxist except for $\mathrm{T}$ and $\mathrm{C} T$ in the solution in the temperature range. In striking contrast to $\mathbf{C D}$. for $\mathbf{C T}$, one sel of signals appeared instead of two sets of signals, indicating that the catenated cyclotrimer (CT) is fluxional owing to the large ring size of $T$ in water even at room temperature. The chemical shift of the phenyl group $\left(-\mathrm{C}_{\mathrm{i}} \mathrm{H}_{4-}\right)$ at $6.20 \mathrm{ppm}$ is a median value between $7.02 \mathrm{ppm}$ (outside $-\mathrm{C}_{6} \mathrm{H}_{4-}$ ) and $5.78 \mathrm{ppm}$ (inside $-\mathrm{C}_{6} \mathrm{H}_{4-}$ ) of
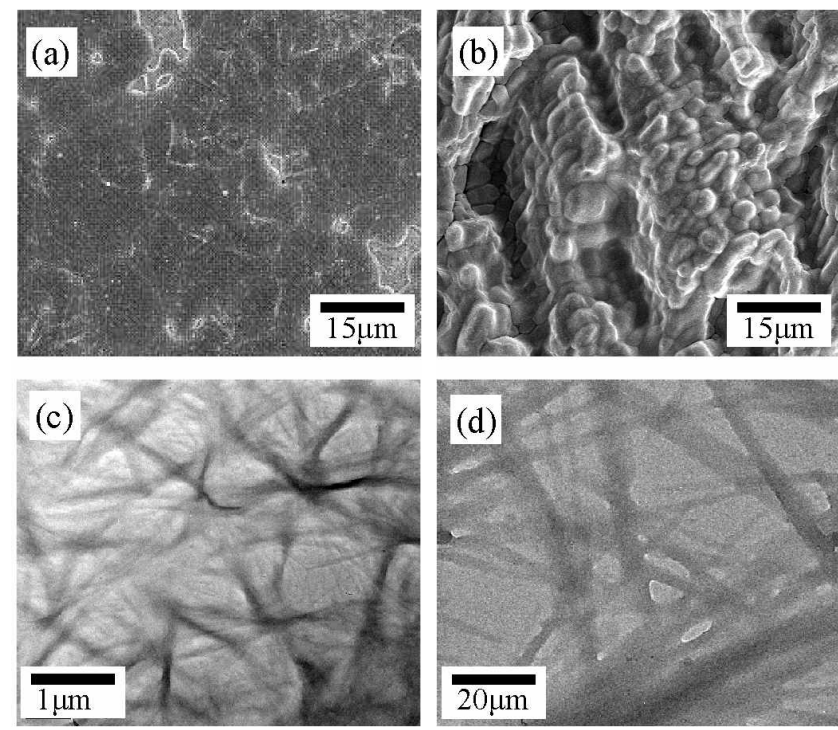

Figure 3. SliM inages of hrdrogel-surface aflor quick-freezing at I"C (al) and at $38^{\circ} \mathrm{C}$ (b). []:M images of dried bydrogel in pure water ( $1 \%$ solute (e) and $0.5 \%$ solute (d)).
CD. The CT increased with the concentration. but contele conversion did not oceur in contrast to $\mathbf{D}$ species owing to the low water-solubility of $\mathrm{T}$ species. That is, $\mathrm{T}$ is less watersoluble than D. The low concentrated aqueous solution is an obstacle to measure the low temperature NMR spectrum for the separated signals of CT. Of course, ${ }^{1} \mathrm{H}$ NMR spectra of I (meda) $\left.\mathrm{Pd}(\mathrm{L})\right|_{3}\left(\mathrm{NO}_{3}\right)_{6}$ in a mixlure of $\mathrm{D}_{2} \mathrm{O}$ and $\mathrm{McOH}-d_{4}(15$ mM) indicate that the CT species drastically decreases (Figure 2). Furthermore. salt cffects on the aqueous media were observed in aqueous solution (Supporting Information: Fig. S5). That is, the catenated species increases with the addition of salts in aqueous solution. In order to more elcarly characterize the species in aqueous solution. their mass data were oblained. The mass data of $\mid$ (tmeda) $\left.\mathrm{Pd}(\mathrm{L})\right|_{3}\left(\mathrm{NO}_{3}\right)_{6}$ were obtained for the aqueous solution containing a $5: 6$ mixture of $T$ and CT (as confirmed by ${ }^{1} \mathrm{H}$ NMR spectrum). The FAB mass data (matrix: nitrobens lalcohol) of $|(\operatorname{meda}) \mathrm{Pd}(\mathrm{L})|_{3}$ $\left(\mathrm{NO}_{3}\right)_{6}\left(m e=570.2\right.$ |CT-6 $\mathrm{NO}_{3}-\left.\mathrm{HNO}_{3}\right|^{(i-}$ or $\left[\mathrm{T}-3 \mathrm{NO}_{3}-\left.\mathrm{HNO}_{3}\right|^{3 .}\right.$ : 632. I |CT-6 $\left.\mathrm{NO}_{3}\right|^{6}$ or $\left|\mathrm{T}-3 \mathrm{NO}_{3}\right|^{3}: 916.1$ [CT-4NO $\left.-\mathrm{HNO}_{3}\right]^{4}$ or $\left|\mathbf{T}-2 \mathrm{NO}_{3}-\mathrm{HNO}_{3}\right|^{-*}: 980.0\left[\mathbf{C T}-4 \mathrm{NO}_{3}\right]^{4}$ or $\left[\mathbf{T}-\left.2 \mathrm{NO}_{3}\right|^{-}\right.$: $1082.0\left|\mathrm{CT}-3 \mathrm{NO}_{3}-4 \mathrm{HNO}_{3}\right|^{3-}=1144.2$ |CT-3NO $3 \mathrm{~N}_{3}-\left.3 \mathrm{HNO}_{3}\right|^{3 .}$ : $1266.0\left|\mathrm{CT}-3 \mathrm{NO}_{3}-\mathrm{HNO}_{3}\right|^{3}: 1327.9$ [CT-3NO$\left.{ }_{3}\right|^{3}$ ) indicaled that $\mid$ (tmcda)Pd( $\left.(\mathrm{L})\right|_{3}\left(\mathrm{NO}_{3}\right)_{1}$ cocxists as a mixture of $\mathrm{T}$ and $\mathrm{CT}$ in water (Supporting Information: mass of $|(\operatorname{meda}) \mathrm{Pd}(\mathrm{L})|_{3-}$ $\left(\mathrm{NO}_{3}\right)_{4}$ and $\left.\mid(\mathrm{cn}) \mathrm{Pd}(\mathrm{L})_{-}\left(\mathrm{NO}_{3}\right)_{4}\right)$. The anion exchange of |(meda) $\left.\mathrm{Pd}(\mathrm{L})\right|_{3}\left(\mathrm{NO}_{3}\right)_{i}$ with $\mathrm{PF}_{<i}$ was attcmpted to identif. the product but unfortunately afforded only a cyclodimer. |(tmeda) $\mathrm{Pd}(\mathrm{L})]_{2}\left(\mathrm{PF}_{t}\right)_{4}$ (Supporting Iuformation: CCDC No: 684329: Fig. S3). That is the counteranions play important role in the formation of the present labile metallacyclization. Ol course, the aromatic $\mathrm{H} N M R$ of $\mid\left.($ tmeda $) \mathrm{Pd}(\mathrm{L})\right|_{3}\left(\mathrm{NO}_{3}\right)_{6}$ is significantly different form that of $\mid($ tmeda $) \mathrm{Pd}(\mathrm{L})]_{2}\left(\mathrm{PF}_{(}\right)$in acetone (Supporting Information). indicating that [(tmeda)$\left.\operatorname{Pd}(\mathrm{L})\right|_{3}\left(\mathrm{NO}_{3}\right)_{6}$ is cyclotrimer rather than exclodimer in the solution.

Hydrogelation. Surprisingly the hydrogelation of a mixture of $\mathrm{T}$ and $\mathrm{CT}$ in water below $2{ }^{\circ} \mathrm{C}$ was obscrved. as shown in Scheme 1 . The reaction of an aqueous solution $(15 \mathrm{~mL})$ of (tmeda) Pd( $\left.\mathrm{NO}_{3}\right)_{2}$ ( $44 \mathrm{mg}, 0.15 \mathrm{mmol}$ ) with a methanol (10 $\mathrm{mL}$ ) solution of $\mathrm{L}(53 \mathrm{mg}$. $0.15 \mathrm{mmol}$ ) was caricd out for $3 \mathrm{~h}$ at room temperature. The reaction solution was filtered and reduced to an aqucous solution of $5 \mathrm{~mL}$. The safe-kecping of the aqueous solution below 2 " $\mathrm{C}$ affords hydrogel containing $98.5 \%$ water. The hydrogel changed to sol at $38{ }^{\circ} \mathrm{C}$, and to clear solution at $78^{\circ} \mathrm{C}$. This is a reproducible process with sol/gel. The hydrogels at both 1 "C and $38^{\circ} \mathrm{C}$ were quickfreced by a Jet Freerer JFD-030. SEM images of the fromen surfaces were obtained (Figure 3(a) and 3(b)). The two SEM images reveal differences in the microstructures. The surface at ${ }^{\circ} \mathrm{C}$ was smooth whercas at $38{ }^{\circ} \mathrm{C}$ it consisted of winding ripples, indicating that the lydrogel at $38^{\circ} \mathrm{C}$ was fluidic. Differences in the surface between $1{ }^{\circ} \mathrm{C}$ and $38^{\prime \prime} \mathrm{C}$ seem to be the dominant contributor to the fluidic bchavior. TEM photographs (Figure 3(c) and 3(d)) show the morphology of the dried hydrogel prepared in pure water. The morphology shows a nelwork struclure composed of fibers with nano dimension which is similar to the Maitrats results for the discrete hydrophobic pocket molecule." Eren though the 
mechanism of hydrogelation is not clear at this stage. electrostatic interaction through $\mathrm{NO}_{3}^{-}$as a mediator and hydrophobic interaction via a misture of fluxional CT and T may be responsible for the formation of network fibers.

Organic additives and/or polymers have been used to control the formation of hydrogel, ${ }^{11-13}$ the present hydrogelation of discrete metal complexes described in this paper is unprecedented. This system is an effective means of clearly showing the difference in motion between $\mathbf{D}$ and $\mathbf{T}$. The $\mathbf{D}$ species is similar to the Fujita's results. ${ }^{*}$ but the $\mathbf{T}$ species is unprecedented in the catenation. Indeed. the most significant difference between $\mathbf{D}$ and $\mathbf{T}$, as established by the ${ }^{\mathrm{H}} \mathrm{H}$ NMR spectra, may be ascribed to the molecular motion. That is, CD is rigid whereas $\mathbf{C T}$ is fluxional in aqueous solution. The rigid D produces a simple solid product, but the fluxional largecyclic $\mathbf{T}$ affords hydrogel in water. Fonmation of the hydrogel can be ascribed to a suitable combination of the hyrdrophobic Si properties, the charged hydrophilic $\mathrm{NO}_{3}^{-}$, electrostatic interaction. and the fluxional motion. Another important factor in both catenation and hydrogelation is solvent effects. $\mathbf{T}$ in a mixture of $\mathrm{D}_{-} \mathrm{O}$ and $\mathrm{MeOH}-d_{4}$ was not hydrogelated. and $\mathbf{C T}$ was drastically decreased with addition of methanol. Thus. the compound in organic solvents did not form the gel. The intermolecular interactions of fluxional metallacyclic molecules via intermediary water molecules seem to be a driving force of the formation of hydrogels. $T$ is more prone to self-assembly due to amphiphilicity and van der Waals interaction, but how this hydrogel is formed from the individual molecules is not clear at this stage. This system is a genuine hydrogelation of discrete metal complexes in water without any organic solvent. These hy'drogels have the ability to sense the changes of $\mathrm{pH}$, temperature, or the concentration.

\section{Conclusions}

The present system shows the subtle coligand effects on metallacyclization and catenation. This fluxional catenated cyclotrimer (CT) is an unprecedented system. The first reversible hydrogelation of discrete metal complexes in pure water without any additives or organic solvent seems to have been induced from equilibrium between fluxional cyclotrimers $(\mathbf{T}+\mathbf{C T})$ in water. This process is a conceptually advanced method of producing hydrogels. The 38 " $\mathrm{C}$ transition temperature and $\mathrm{pH}$ changes of the present hydrogels can contribute to the desirable cyclic materials applicable to sensor technology, transport. and drug delivery system in the human body.

Acknow ledgments. This research was supported by a grant from the Fundamental R\&D Program for Core Technology of Materials funded by the Ministry of Knowledge Economy. Republic of Korea.

Supporting Infomation. FAB mass data of $[(\mathrm{en}) \mathrm{Pd}(\mathrm{L})]=-$ $\left(\mathrm{NO}_{3}\right)_{4}(\mathrm{Fig} . \mathrm{S} 1)$ and $\left[(\right.$ tmeda $) \mathrm{Pd}(\mathrm{L})_{3}\left(\mathrm{NO}_{3}\right)_{6}$ (Fig. S2): X-ray cry'stal structure of $[(\text { tmeda }) \mathrm{Pd}(\mathrm{L})]_{3}\left(\mathrm{PF}_{6}\right)_{4}($ Fig. $\$ 3):{ }^{1} \mathrm{H}$ NMR of $[(\text { tmeda }) \mathrm{Pd}(\mathrm{L})]_{3}\left(\mathrm{NO}_{3}\right)_{6}(\mathrm{a})$ and $\left[(\right.$ tmeda $) \mathrm{Pd}(\mathrm{L})_{2}\left(\mathrm{PF}_{6}\right)_{4}(\mathrm{~b})$ in acetone-d 6 (Fig. S4): ${ }^{1} \mathrm{H}$ NMR spectra of [(tmeda)Pd(L) $]_{3}-$ $\left(\mathrm{NO}_{3}\right)_{6}$ along with addition of $\mathrm{NaNO}_{3}$ (Fig. S5). Crystallographic data for $[(\text { tmeda }) \mathrm{Pd}(\mathrm{L})]_{2}\left(\mathrm{PF}_{6}\right)_{4}$ is deposited at the Cambridge Crystallographic Data Centre under supplementary publication numbers CCDC-684329. Copies of available material may be obtained on application to CCDC. 12 Union Road, Cambridge CB2 1EZ, UK, fax: +4+ 1223336033 , or e-mail: depositaccdc.cam.ac.uk.

\section{References}

1. Chun, I. S.; Lee, K. S.; Do, J.; Hong, Y.; Jung, O.-S. Chem. Lett. 2007,548

2. Chun, I. S.: Kwon, I. A.; Yoon, H. I.: Bae, M. N.; Hong, I.; Jung, O.-S. Angew. Chem., Int Ed. 2007, 46,4960 .

3. Yoon, H. J.; Chun, I. S.; Na, Y, M; Lee, Y.-A; Jung, O.S. Chem. Conmm 2007, 492

4. Zhao, B.; Moore, I. S. Langmiv 2001, 17,4758.

5. Maitra, U.: Mulhopadhyay, S.: Sarkar, A.: Rao, P.; Indi, S. S. Angew Chem. Int Ed. 2001, 40,2281.

6. Zhou, J.-L.; Chen, X.-T; Zheng, Y.-S. Chent. Commun. 2007, 5200

7. Yang, J.; Gu, H.; Zhang, Y.: Wang, L.: Xu, B. Chem. Commum. 2004.208

8. Lehn, T.-M Supranolecular Chemistn: Concepts and Perspectives; VCH: Weinheim, 1995.

9. Suzuki, M:- Yumoto, M; Shirai, H.; Hanabusa, K. Org. Biontol. Chem. 2005, 3, 3073 .

10. Jung, T. H.; Do, Y.; Lee, Y.-A.: Shimizu, T. Chem. Eur. J. 2005, 11,5538

11. Luo, Y,; Dalton, P. D.; Shoichet, M. S. Chem. Mater, 2001, 13. 4087

12. Chujo, Y.; Sada, K:; Saegura, T. Hacromolectules 1993, 26 , 6320 .

13. Pfennig, B. W.; Bocarsly, A. B.: Prudhomme, R. K. J. Am. Chem. Soc. 1993, 115, 2661.

14. Jung, I. H.; Ono, Y.; Hanabusa, K; Shinkai, S. J. Ant. Chem. Soc. $\mathbf{2 0 0 0}, 122,5008$.

15. Hafkamp, R. I. H.; Feiters, M. C.: Nolte, R. T. M. J. Org. Chem. $1999,64,412$

16. Brotin, T.; Utermöhlen, R.: Fages, F.; Bonas-Lalurent, H.; Deswergne, J.-P. J. Chem. Soc., Chent. Conmm 1991, 416.

17. For a recent report on the gelation of $\mathrm{CO}_{2}$, see Shi, $\mathrm{C}$; Huang, $\mathrm{Z}$; Kilic, S.; Xu, T.; Enick, R. M.; Beckman, E. J.; Carr, A. T.; Melendez, R. E.; Hamilton, A. D. Science 1999, $286,1540$.

18. Leinigner, S.; Olenyuk, B.: Stang. P. J. Chem. Rev. 2000, 100, 853.

19. Wang, P; Moorefield, C. N.; Newkome, G. R. Angew. Chent. Int. Ed. 2005, 4 t, 1679 .

20. Grote, Z: Scopelliti, R.; Severin, K. J. Am. Chem. Soc. 2004, 126,16959

21. Na, Y. M.; Noh, T. H.: Chun, I. S.: Lee, Y.-A.; Hong, J.: Iung. O.-S. Inorg. Chem 2008, 47, 1391

22. Fujita, M.; Ibukuro, F; Hagihara, H.; Ogura, K. Nature 1994, 367,720 .

23. Suzuki, K.: Kawano, M.; Fuịita, M. Angew. Chem., Int. Ed. 2007. $\$ 6.2819$.

24. Tohnson, G. L. Horg. Syn. 1966, 8, 242.

25. Park, B. I.; Chun, I. S.; Lee, Y.-A.; Park, K.-M.; Jung, O.-S. horg. Chem. 2006, 45,4310 .

26. Cha, M. S.: Park, B. I.; Kang, H. J.: Yoo, K. H.; Jung, O.-S. Bull. Korean Chem. Soc. 2007, 28, 1057. 